\title{
PERAN RELIGIUSITAS SEBAGAI MODERASI DETERMINAN TINDAKAN PENGGELAPAN PAJAK
}

\author{
Dwi Pujiastuti, Fany Indriyani ${ }^{\bowtie}$ \\ Institut Agama Islam Negeri (IAIN) Salatiga, Indonesia \\ pujiastutidwi07@gmail.com, fanyindriyani@iainsalatiga.ac.id
}

https://doi.org/10.46367/jas.v5i2.432

Received: Nov 15, 2021 Revised: Dec 08, 2021 Accepted: Dec 15, 2021 Published: Dec 21, 2021

\begin{abstract}
The purpose of this research is to show the effect of fairness of tax collection, subjective norms, taxation system, and tax sanctions on tax evasion, which is moderated by religiosity. This study uses a quantitative approach. The data used are primary data derived from questionnaires. The population used are entrepreneurs registered with the cooperative service, small and medium enterprises in the city of Salatiga. The sampling technique used purposive sampling to obtain as many as 33 samples. Data analysis using multiple linear regression and moderated regression analysis (MRA). The results showed that the fairness of tax collection, taxation system, and tax sanctions could not affect the act of tax evasion. Then religiosity cannot be a moderator in the act of tax evasion. However, subjective norms have been shown to influence tax evasion. Subjective norms are suggestions or invitations to those closest to them to comply with tax regulations not to commit tax evasion. Religiosity cannot reduce tax evasion because it is influenced by external factors so that religiosity as an individual value embedded in the person cannot be a component that reduces tax evasion.
\end{abstract}

Keywords: Tax Collection Justice, Subjective Norms, Taxation System, Tax Sanctions, Tax Evasion, Religiosity.

\begin{abstract}
ABSTRAK
Tujuan penelitian ini adalah untuk memperlihatkan pengaruh keadilan pemungutan pajak, norma subjektif, sistem perpajakan, dan sanksi pajak terhadap tindakan penggelapan pajak yang dimoderasi oleh religiusitas. Penelitian ini menggunakan pendekatan kuantitatif. Data yang digunakan merupakan data primer yang berasal dari kuesioner. Populasi yang digunakan adalah pengusaha yang terdaftar di dinas koperasi, usaha kecil dan menengah kota Salatiga. Teknik pengambilan sampel menggunakan purposive sampling, sehingga diperoleh sebanyak 33 sampel. Analisis data menggunakan metode regresi linear berganda dan moderated regression analysis (MRA). Hasil penelitian menunjukkan bahwa keadilan pemungutan pajak, sistem perpajakan dan sanksi pajak tidak dapat mempengaruhi tindakan penggelapan pajak. Kemudian religiusitas tidak dapat menjadi moderator dalam tindakan penggelapan pajak. Meskipun demikian, norma subjektif terbukti dapat mempengaruhi tindakan penggelapan pajak. Norma subjektif merupakan saran atau ajakan orang terdekat untuk mematuhi peraturan perpajakan sehingga tidak melakukan tindakan penggelapan pajak. Religiusitas
\end{abstract}


tidak mampu menurunkan tindakan penggelapan pajak sebab dipengaruhi oleh faktor eksternal sehingga religiusitas sebagai nilai individu yang tertanam dalam diri pribadi, tidak dapat menjadi komponen yang menurunkan tindakan penggelapan pajak.

Kata Kunci: Keadilan Pemungutan Pajak, Norma Subjektif, Sistem Perpajakan, Sanksi Pajak, Penggelapan Pajak, Religiusitas.

\section{PENDAHULUAN}

Pembangunan sarana dan prasarana dalam rangka meningkatkan kesejahteraan masyarakat merupakan tugas pemerintah. Terwujudnya tugas pemerintah untuk melaksanakan pembangunan harus didukung oleh kontribusi pajak dari masyarakat. Namun masalah pemungutan pajak merupakan kendala yang sering dihadapi pemerintah. Wajib pajak terkadang memberikan perlawanan aktif demi menghindari jumlah pajak dengan cara penggelapan pajak (Mardiasmo 2016; Sundari 2019). Penggelapan pajak merupakan salah satu faktor yang dapat menghambat pemerintah dalam pembangunan infrastruktur negara. Berdasarkan data dari kantor pelayanan pajak pratama kota Salatiga bahwa penerimaan pajak tahun 2015-2020 belum maksimal, karena penerimaan pajak dari tahun ke tahun belum mencapai target yang ditetapkan oleh pemerintah. Sedangkan data tingkat kepatuhan wajib pajak orang pribadi dari tahun 2015-2020 menunjukkan angka yang semakin menurun. Hal tersebut mengindikasikan bahwa adanya tindakan wajib pajak yang tidak mematuhi undang-undang yang berlaku.

Penelitian mengenai tindakan penggelapan pajak sudah pernah dilakukan oleh beberapa peneliti dengan hasil yang beragam. Penelitian yang dilakukan oleh Kusnadi and Rinika (2019); Suryaputri and Averti (2019) menghubungkan tindakan penggelapan pajak dengan keadilan pemungutan pajak, berhasil membuktikan bahwa keadilan pemungutan pajak berpengaruh positif terhadap penggelapan pajak. Namun hal ini berbeda dengan penelitian yang dilakukan oleh Ardi, Trimurti, and Suhendro (2016); Marlina (2018) yang menyatakan bahwa keadilan pajak tidak berpengaruh terhadap persepsi wajib pajak mengenai penggelapan pajak. Penelitian Wanarta and Mangoting (2014) mencari pengaruh norma subjektif terhadap niat melakukan penggelapan pajak. Hasil yang diperoleh bahwa norma subjektif mempunyai pengaruh positif terhadap niat wajib pajak dalam melakukan penggelapan pajak.

Hal ini berbeda dengan penelitian yang dilakukan oleh Surahman and Putra (2018) yang menemukan bahwa norma subjektif tidak mempunyai pengaruh terhadap persepsi wajib pajak mengenai etika penggelapan pajak. Terhadap sistem pemungutan pajak khususnya dengan Self Assessment System seringkali menimbulkan perselisihan antara pihak pajak dengan wajib pajak yang menjadi sengketa pajak. Sistem perpajakan yang diteliti oleh Fatimah and Wardani (2017) mengemukakan bahwa sistem perpajakan tidak berpengaruh terhadap penggelapan pajak. Namun penelitian yang dilakukan oleh Kusnadi and Rinika (2019) menyatakan bahwa sistem pemungutan pajak berpengaruh signifikan terhadap penggelapan pajak. Selanjutnya faktor sanksi pajak yang bersifat tegas, mengikat dan dapat menimbulkan efek jera (Agus, Umiyati, and Kurniawan 2019). Penelitian yang dilakukan oleh Kusnadi and Rinika (2019) mengatakan bahwa sanksi keterlambatan perpajakan tidak berpengaruh terhadap penggelapan 
pajak. Sedangkan penelitian yang dilakukan oleh Felicia and Erawati (2017) mengemukakan bahwa sanksi pajak berpengaruh terhadap persepsi wajib pajak mengenai etika penggelapan pajak. Berdasarkan dari hasil penelitian tersebut perlu dilakukan penelitian ulang dengan menambahkan religiusitas sebagai variabel moderasi.

Tindakan penggelapan pajak melalui cara-cara yang illegal termasuk dalam kategori fraud. Terjadinya fraud disebabkan karena tiga hal yaitu tekanan, kesempatan dan rasionalisasi (Cressey 1950). Oleh sebab itu penelitian ini bertujuan untuk menunjukkan pengaruh keadilan pemungutan pajak, norma subjektif, sistem perpajakan dan sanksi pajak terhadap tindakan penggelapan pajak. Kemudian untuk menunjukkan moderasi religiusitas dapat memperkuat atau memperlemah pengaruh antara keadilan pemungutan pajak, norma subjektif, sistem perpajakan, sanksi pajak terhadap tindakan penggelapan pajak. Religiusitas merupakan tingkat individu menjalankan ajaran yang diyakininya dengan tindakan yang dilakukan dalam keseharian (Dharma, Agusti, and Kurnia 2016). Sehingga jika seseorang berada pada tingkat religiusitas yang tinggi akan dapat menghindari perbuatan yang dilarang oleh agama. Sama halnya dengan penggelapan pajak, dianggap sebagai perbuatan yang dapat menyebabkan kerugian pada diri sendiri dan banyak orang bahkan melingkupi satu negara.

\section{TELAAH LITERATUR}

\section{Fraud Triangle Theory}

Teori fraud triangle oleh Cressey (1950) menyatakan bahwa terjadi adanya kecurangan (fraud) disebabkan karena tiga hal. Pertama, tekanan adalah faktor yang dapat mendorong seseorang dalam melakukan tindakan curang. Kedua, kesempatan merupakan peluang yang dapat menyebabkan seseorang melakukan tindakan kecurangan. Salah satu penyebab kecurangan karena adanya kesempatan merupakan kurangnya pengawasan internal. Ketiga, rasionalisasi yaitu pelaku mencari pembenaran untuk membenarkan dari perbuatan curang yang dilakukan (Priantara 2013, 47).

\section{Penggelapan Pajak}

Penggelapan pajak yaitu usaha wajib pajak untuk mengurangi jumlah pajak yang harus dibayar, dimana melanggar ketentuan yang telah ditetapkan pada perundang-undangan dalam bidang perpajakan (Nugroho 2017, 2). Suatu tindakan penggelapan pajak oleh wajib pajak untuk memperkecil jumlah hutang pajak menggunakan lagkah melanggar perundang-undangan perpajakan (Haq and Puspita 2019).

\section{Keadilan Pemungutan Pajak}

Keadilan pemungutan pajak harus adil dalam pembuatan undang-undang maupun pada pelaksanaannya. Adil yang dimaksud oleh perundang-undangan haruslah dikenakan pajak secara merata, dan harus menyesesuaikan dengan kemampuan wajib pajak. Sedangkan apabila diperhatikan dari segi pelaksanaan yang adil adalah pemerintah memberikan hak bagi wajib pajak dapat mengajukan penundaan pembayaran pajak, banding, atau keberatan atas jumlah pajak yang telah ditetapkan (Mardiasmo 2016, 4). 


\section{Norma Subjektif}

Menurut Ajzen (1991) bahwa norma subjektif memfokuskan kepada tekanan sosial yang dipersepsikan dalam tindak perilaku. Norma subjektif merupakan suatu keyakinan seseorang terhadap pihak luar yang dapat menjadi referensi penting bagi individu untuk menyetujui atau menolak sesuatu keputusan. Dunia perpajakan norma subjektif dapat mempangaruhi niat wajib pajak untuk melakukan pelanggaran perpajakan (Fatimah and Wardani 2017).

\section{Sistem Perpajakan}

Menurut S., Alam (2014, 151-152) bahwa sejarah menyebutkan beberapa sistem yang telah dilakukan di Indonesia. Pertama, official assessment system dilakukan mulai dari adanya penetapan pajak sampai dengan tahun 1967. Sistem ini pemerintah (fiskus) mempunyai wewenang yang penuh sebagai pemungut pajak. Kedua, semi self assessment system dan withholding system dilakukan tahun 1968-1983. Sistem ini menyerahkan kuasa kepada kedua belah pihak antara fiskus dan wajib pajak. Dengan anggapan bahwa wajib pajak dapat menghitung sendiri pajak terutang. Namun, besarnya pajak yang sesungguhnya akan ditetapkan oleh fiskus. Witholding system merupakan pemungutan pajak yang dilakukan oleh pihak ketiga. Ketiga, full self assessment system dilakukan tahun 1983 secara efektif dilaksanakan tahun 1984 hingga saat ini. Sistem ini menyerahkan kuasa penuh terhadap wajib pajak untuk berperan aktif menghitung besar jumlah pajak terutang sampai dengan melaporkan sendiri pajak di kantor pelayanan pajak. Namun fiskus bertugas mengawasi pajak yang telah disetorkan oleh wajib pajak.

\section{Sanksi Perpajakan}

Sanksi pajak merupakan alat dalam pencegahan tindakan pelanggaran norma perpajakan (Hanindita and Retnani 2019). Sanksi perpajakan terdiri dari sanksi administrasi dan sanksi pidana. Sanksi administrasi yaitu pembayaran kerugian ke pemerintah (fiskus), terkhusus berupa kenaikan dan bunga. Menurut ketentuan perundang-undangan mengenai pajak ada 3 macam yang terdapat pada sanksi administrasi berupa kenaikan, denda, serta bunga. Sanksi Pidana merupakan penderitaan, terdapat tiga macam sanksi pidana yang ada di indonesia yaitu denda pidana, pidana kurungan, pidana penjara.

\section{Religiusitas}

Banyak istilah yang menyebut agama atau religi seperti dalam bahasa Inggris (religion), bahasa Belanda (religie), bahasa Latin (religio/relegare), dan dalam bahasa Arab (ad-Dien) (Palupi 2013). Religiusitas yaitu seberapa dalam seseorang dapat memahami ilmu ajaran agama yang dianutnya serta luas pengetahuan, hingga mempunyai sikap toleransi terhadap agama selain yang diimani (Makrifah and Trishananto (2021). Religiusitas tidak hanya dilakukan dengan ibadah tetapi juga aktivitas lain yang mendorong dengan dasar agama (Purwati 2016). Bukan hanya aktivitas yang dapat dilihat individu mempunyai tingkat religiusitas yang tinggi tetapi juga sesuatu yang tidak dapat dilihat yaitu hati yang tulus ikhlas karena Allah SWT. 


\section{Keadilan Pemungutan Pajak Terhadap Tindakan Penggelapan Pajak}

Keadilan pajak dianggap penting bagi wajib pajak. Theory of fraud triangle menjelaskan faktor dari kecurangan adalah tekanan yang menghimpit, peluang, dan anggapan rasional dari pelaku. Tindakan seseorang setelah mengamati sesuatu hal dengan panca indranya. Sehingga setelah wajib pajak mengamati bahwa berkurangnya keadilan pajak wajib pajak dapat melakukan penggelapan pajak. Didukung oleh penelitian Fatimah and Wardani (2017); Sondakh, Sabijono, and Pusung (2019) yang mengemukakan bahwa keadilan pemungutan pajak berpengaruh negatif secara signifikan terhadap penggelapan pajak, maka dapat dirumuskan hipotesis pertama:

$\mathbf{H}_{1}$ : keadilan pemungutan pajak berpengaruh negatif dan signifikan terhadap tindakan penggelapan pajak.

\section{Norma Subjektif Terhadap Tindakan Penggelapan Pajak}

Wajib pajak yang menganggap pihak eksternal penting dalam pengambilan keputusan. Pengaruh yang baik dari luar akan membuat wajib pajak melakukan tidakan yang baik pula. Hasil penelitian yang dilakukan oleh Datulalong and Susanto (2021) menemukan bahwa norma subjektif berpengaruh negatif signifikan terhadap penggelapan pajak, maka dapat dirumuskan hipotesis kedua:

$\mathbf{H}_{2}$ : norma subjektif berpengaruh negatif dan signifikan terhadap tindakan penggelapan pajak.

\section{Sistem Perpajakan Terhadap Tindakan Penggelapan Pajak}

Di indonesia pemungutan pajak menggunakan self assessment system yang mewajibkan wajib pajak menghitung sampai melaporkan pajak terutangnya sendiri kepada pemerintah dan terdapat pengawasan dari fiskus. Sehingga ketika sistem pajak tidak sesuai dengan wajib pajak, maka wajib pajak tidak dapat melakukan kecurangan karena pada teori fraud triangle mengatakan adanya kesempatan untuk berbuat kecurangan. Penelitian yang dilakukan oleh Paramita and Budiasih (2016); Rifani, Mursalim, and Ahmad (2019) yang menyatakan bahwa sistem perpajakan berpengaruh negatif dan signifikan terhadap penggelapan pajak, maka dapat dirumuskan hipotesis yang ketiga:

H3$_{3}$ : sistem perpajakan berpengaruh negatif dan signifikan terhadap tindakan penggelapan pajak.

\section{Sanksi Pajak Terhadap Tindakan Penggelapan Pajak}

Sanksi pajak yang ditetapkan bagi pelanggar ditetapkan sesuai dengan yang telah dilakukan. Persepsi wajib pajak akan mengamati bagaimana proses sanksi terhadap pelanggar. Sanksi yang dianggap baik wajib pajak akan merasa takut ketika melakukan pelanggaran pajak. Didukung oleh penelitian Maghfiroh and Fajarwati (2016); Wijaya and Jannah (2017) yang menyatakan sanksi pajak berpengaruh negatif dan signifikan terhadap persepsi wajib pajak mengenai etika penggelapan pajak, maka ditetapkan hipotesis yang keempat:

$\mathbf{H}_{4}$ : sanksi pajak berpengaruh negatif dan signifikan terhadap tindakan penggelapan pajak. 


\section{Keadilan Pemungutan Pajak Terhadap Tindakan Penggelapan Pajak Dimoderasi Religiusitas}

Keadilan pemungutan pajak merupakan upaya pemerintah untuk mengurangi tindakan penggelapan pajak, sehingga edukasi terhadap masyarakat tentang pentignya pajak harus terus dilakukan. Menurut Palil, Rusyidi, and Ahmad (2013) ketika edukasi ini dilakukan terhadap orang-orang yang religius, maka kepatuhan mereka terhadap penegakan pajak menjadi lebih baik. Sehingga dapat dirumuskan hipotesis kelima:

H5: religiusitas dapat memperlemah pengaruh keadilan pemungutan pajak terhadap tindakan penggelapan pajak.

\section{Norma Subjektif Terhadap Tindakan Penggelapan Pajak Dimoderasi Religiusitas}

Lingkungan yang baik akan mempengaruhi tindakan baik pula, sebaliknya apabila lingkungan yang buruk dapat mempengaruhi hal yang kurang baik terhadap tindakan wajib pajak. Moralitas masyarakat menjadi salah satu indikator penting dalam pencegahan tindakan penggelapan pajak sebagaimana penelitian yang dilakukan Stack and Kposowa (2006) yang menemukan bahwa dengan moralitas yang ada dimasyarakat dan moderasi religiusitas dapat mengurang tindakan penggelapan pajak. Berdasarkan hal tersebut maka hipotesis keenam dapat dirumuskan:

$\mathbf{H}_{6}$ : religiusitas dapat memperlemah pengaruh norma subjektif terhadap tindakan penggelapan pajak.

\section{Sistem Perpajakan Terhadap Tindakan Penggelapan Pajak Dimoderasi Religiusitas}

Penetapan self assessment system merupakan sistem yang menuntut kejujuran wajib pajak dalam melakukan mematuhi aturan pajak. Berdasarkan penelitian Atmoko (2021) dapat diketahui bahwa kejujuran wajib pajak dalam melakukan pengisian pajak secara mandiri jika dibantu religiusitas dapat menurunkan tingkat penggelapan pajak, sehingga berdasarkan hal tersebut maka dapat dirumuskan hipotesis ketujuh:

$\mathbf{H}_{7}$ : religiusitas dapat memperlemah pengaruh sistem perpajakan terhadap tindakan penggelapan pajak.

\section{Sanksi Pajak Terhadap Tindakan Penggelapan Pajak Dimoderasi Religiusitas}

Hukuman yang sesuai dengan tindakan melanggar pajak akan membuat wajib pajak mempunyai rasa takut untuk melakukannya. Namun, apabila penggelapan pajak hukumannya dianggap ringan wajib pajak tidak mempertimbangkannya. Hukuman ini memiliki dua perspektif, yaitu hukuman secara eksternal yang merupakan sanksi nyata atas suatu pelanggaran dan sanksi internal yang merupakan bentuk penyesalan terhadap pelanggaran. Religiusitas sangat berpengaruh pada bentuk sanksi internal (Koster, Goudriaan, and Schans 2009). Religiusitas diharapkan akan menurunkan tindakan penggelapan pajak, sehingga dapat dirumuskan hipotesis kedelapan:

$\mathbf{H}_{8}$ : religiusitas dapat memperlemah pengaruh sanksi pajak terhadap tindakan penggelapan pajak. 


\section{METODE PENELITIAN}

Penelitian ini berjenis penelitian kuantitatif dengan menggunakan data primer yang diperoleh dengan menyebar kuesioner kepada responden. Skala yang digunakan dalam pernyataan kuesioner merupakan skala semantic defferensial dengan skor 1-10. Populasi yang digunakan adalah usaha mikro, kecil dan menengah (UMKM) yang terdaftar di dinas koperasi, usaha kecil dan menengah kota Salatiga sebanyak 14.440 pengusaha. Pengambilan sampel dilakukan dengan metode purposive sampling dengan kriteria: UMKM yang memiliki nomor pokok wajib pajak (NPWP) dan pengusaha yang beragama Islam. Pengumpulan data dilakukan dengan cara membagikan kuisioner secara langsung kepada wajib pajak yang memiliki NPWP sebanyak 75 responden. Namun kuisioner yang berhasil kembali hanya 62 responden. Kemudian dari 62 responden yang mengembalikan kuesioner, 29 responden bukan beragama Islam, sehingga diperoleh jumlah sampel akhir sebanyak 33 responden. Analisis data menggunakan metode regresi linear berganda dan moderated regression analysis (MRA) dengan pengujian statistik deskriptif, validitas, reliabilitas, normalitas, multikolinearitas, heteroskedasitas, $\mathrm{t}, \mathrm{f}$, dan koefisien determinan.

\section{HASIL DAN PEMBAHASAN PENELITIAN}

\section{Profil Responden}

Berdasarkan kuisioner yang terkumpul maka dapat dideskripsikan profil responden. Berdasarkan usia wirausaha jumlah usia 21-30 tahun sebesar 6,1\% (2 orang), usia 31-40 tahun adalah 39,4\% (13 orang), usia 41-50 tahun sebesar $36,4 \%$ (12 orang) dan usia di atas 50 tahun sebesar 18,2\% (6 orang). Hal ini berarti responden masih berada dalam usia produktif dalam bekerja dan mendapatkan penghasilan dan dapat membayar pajak. Berdasarkan jenis kelamin, 22 orang berjenis kelamin perempuan $(66,6 \%)$ dan 11 orang berjenis kelamin lakilaki $(33.3 \%)$.

\section{Statistik Deskriptif}

Tabel 1. Hasil Statistik Deskriptif

\begin{tabular}{lcccc}
\hline & $\boldsymbol{N}$ & Minimum & Maximum & Mean \\
\hline Keadilan Pemungutan Pajak & 33 & 4 & 40 & 28,85 \\
Norma Subjektif & 33 & 10 & 40 & 30,39 \\
Sistem Perpajakan & 33 & 3 & 30 & 21,58 \\
Sanksi Pajak & 33 & 4 & 40 & 31,94 \\
Tindakan Penggelapan Pajak & 33 & 5 & 33 & 9,67 \\
Religiusitas & 33 & 25 & 30 & 29,06 \\
\hline
\end{tabular}

Sumber: data primer (diolah)

Statistik deskriptif berfungsi dapat memberikan gambaran tentang nilai minimum, maksimum, rata-rata (mean) (Ghozali 2018, 19). Berdasarkan Tabel 1, dapat dilihat bahwa nilai keadilan pemungutan pajak nilai minimum adalah 4 , nilai maksimum adalah 40 , dan nilai rata-rata adalah 28,85 . Nilai norma subjektif minimum adalah 10 dan maksimum adalah 40, dan nilai rata-rata sebesar 30,39. 
Sistem perpajakan memiliki nilai minimum sebesar 3, nilai maksimum sebesar 30, dan nilai rata-rata adalah 21,58. Sanksi pajak memiliki nilai minimum sebesar 4, nilai maksimum sebesar 40, dan nilai rata-rata sebesar 31,94. Tindakan penggelapan pajak memiliki nilai minimum sebesar 5, nilai maksimum sebesar 33, dan nilai rata-rata sebesar 9,67. Religiusitas memiliki nilai minimum sebesar 25, nilai maksimum sebesar 30, dan rata-rata sebesar 29,06.

\section{Uji Kualitas Dan Reliabilitas Data}

Berdasarkan pengujian validitas yang dilakukan diperoleh nilai $r_{h i t u n g}$ tertinggi sebesar 0,988 pada variable sanksi pajak dan nilai $r_{\text {hitung }}$ terendah sebesar 0,655 pada variable norma subjektif. Sedangkan menentukan nilai $r_{\text {tabel }}$ berdasarkan df $=\mathrm{n}-2=33-2=31$, jika dilihat pada tabel distribusi $\mathrm{r}$ maka diperoleh $r_{\text {tabel }}$ sebesar 0,344. Instrument dikatakan valid jika $r_{\text {hitung }}>r_{\text {tabel. }}$. Pengujian validitas ini menunjukkan bahwa butir-butir soal yang diberikan kepada 33 responden dengan nilai $r_{\text {hitung }}>r_{\text {tabel }}$, sehingga data dapat dinyatakan valid.

Pengujian reliabilitas juga dilakukan untuk mengetahui konsistensi dari indikator yang membentuk variable. Variabel dikatakan reliabel ketika nilai cronbach alpha $>0,70$. Penelitian ini menunjukkan bahwa nilai cronbach alpha pada variabel keadilan pemungutan pajak sebesar 0,928, norma subjektif sebesar 0,812, sistem perpajakan sebesar 0,881, sanksi pajak sebesar 0,974, tindakan penggelapan pajak sebesar 0,856, dan religiusitas sebesar 0,772. Berdasarkan nilai cronbach alpha semua variabel $>0,70$, sehingga data dapat dinyatakan reliabel.

\section{Uji Normalitas}

Tabel 2. Hasil Uji Normalitas

\begin{tabular}{llc}
\hline & & Unstandardized Residual \\
\hline$N$ & & 33 \\
Normal & Mean & 0,0000000 \\
Parameters & Std. Deviation & 5,55403224 \\
Most Extreme & Absolute & 0,134 \\
Differences & Positive & 0,134 \\
& Negative & $-0,088$ \\
Test Statistic & & 0,134 \\
Asymp. Sig. (2-tailed) & 0,141 \\
Sumber: data primer (diolah)
\end{tabular}

Pengujian normalitas menggunakan uji statistik non-paramertic kolmogorov-smirnov $(K-S)$. Tabel 2 menunjukkan bahwa besaran nilai test statistic kolmogorof-smirnov sebesar 0,134 dan nilai signifikansi sebesar 0,141. Nilai signifikansi lebih besar dari 0,05, sehingga dapat dikatakan bahwa data residual berdistribusi normal.

\section{Uji Multikolinieritas}

Pada Tabel 3 hasil perhitungan masing-masing variabel menunjukkan nilai tolerance > 0,10 dan nilai VIF pada masing-masing variabel menunjukkan < 10,00. Sehingga didapat dikatakan bahwa pada variabel bebas dan variabel moderasi tidak terjadi multikolinearitas. 
Tabel 3. Hasil Uji Multikolinieritas

\begin{tabular}{lcc}
\hline \multicolumn{1}{c}{ Variabel } & Tolerance & VIF \\
\hline Keadilan Pemugutan Pajak & 0,308 & 3,250 \\
Norma Subjektif & 0,597 & 1,676 \\
Sistem Perpajakan & 0,196 & 5,096 \\
Sanksi Pajak & 0,534 & 1,873 \\
Religiusitas & 0,973 & 1,028 \\
\hline Sumber: data primer (diolah) & &
\end{tabular}

Sumber: data primer (diolah)

\section{Uji Heterokedastisitas}

Tabel 4. Hasil Uji Heterokedastisitas

\begin{tabular}{cccc}
\hline $\boldsymbol{R}$ & $\boldsymbol{R}$ Square & $\begin{array}{c}\text { Adjusted } \\
\boldsymbol{R} \text { Square }\end{array}$ & $\begin{array}{c}\text { Std. Error of } \\
\text { the Estimate }\end{array}$ \\
\hline 0,734 & 0,539 & 0,297 & 179,41022 \\
\hline \multicolumn{2}{l}{ Sumber: data primer (diolah) }
\end{tabular}

Berdasarkan Tabel 4 dapat dijelaskan bahwa Chi-Square $_{\text {hitung }}=\mathrm{N}$ x $R$

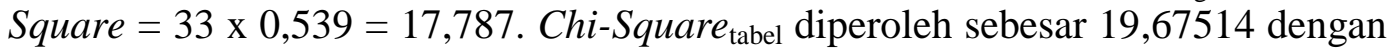

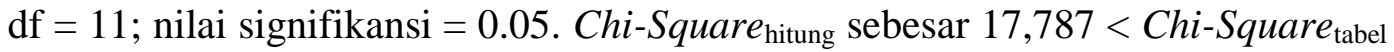
sebesar 19,67514. Sehingga dapat dikatakan bahwa terjadi homoskedastisitas atau tidak terjadi gejala heteroskedastisitas.

\section{Uji t}

Tabel 5. Hasil Uji t

\begin{tabular}{lccc}
\hline \multicolumn{1}{c}{ Variable } & $\boldsymbol{a} / \boldsymbol{B}$ & $\boldsymbol{t}$ & Sig. \\
\hline Konstanta & 24,845 & 4,342 & 0,000 \\
Keadilan Pemugutan Pajak & $-0,353$ & $-1,641$ & 0,112 \\
Norma Subjektif & $-0,596$ & $-3,300$ & 0,003 \\
Sistem Perpajakan & 0,351 & 1,088 & 0,286 \\
Sanksi Pajak & 0,174 & 1,271 & 0,214 \\
Keadilan Pemungutan Pajak * Religiusitas & $-0,011$ & $-0,072$ & 0,943 \\
Norma Subjektif* Religiusitas & 0,000 & $-0,007$ & 0,994 \\
Sistem Perpajakan * Religiusitas & $-0,157$ & $-0,600$ & 0,553 \\
Sanksi Pajak * Religiusitas & $-0,385$ & $-0,467$ & 0,644 \\
\hline Sumber: data primer (diolah) & & &
\end{tabular}

Tabel 5 merupakan hasil uji t yang berasal dari regresi linear berganda dan moderated regression analysis (MRA). Uji t digunakan untuk melakukan pengujian hipotesis, dimana diperlukan nilai $t_{\text {tabel }}$. Pada pengujian ini diperoleh nilai $t_{\text {tabel }}$ sebesar 2,052 dan tingkat signifikansi sebesar 0,05. Berdasarkan Tabel 5 , variabel keadilan pemungutan pajak diperoleh nilai $t_{\text {hitung }}$ sebesar $-1,641$ dan nilai sig. sebesar 0,112 , dimana $-t_{\text {hitung }}>-t_{\text {tabel }}(-1,641>-2,052)$ dan sig. $>0,05$ $(0,112>0,05)$. Hasil ini menunjukkan bahwa keadilan pemungutan pajak tidak berpengaruh dan tidak signifikan terhadap tindakan penggelapan pajak, sehingga $\mathbf{H}_{1}$ ditolak. Variabel norma subjektif diperoleh nilai koefisien negatif, nilai $t_{\text {hitung }}$ sebesar $-1,641$ dan nilai sig. sebesar 0,112 , dimana $-t_{\text {hitung }}>-t_{\text {tabel }}(-3,300<-2,052)$ 
dan sig. $<0,05(0,003<0,05)$. Hasil ini menunjukkan bahwa norma subjektif berpengaruh negatif dan signifikan terhadap tindakan penggelapan pajak, sehingga $\mathbf{H}_{2}$ diterima.

Variabel sistem perpajakan diperoleh nilai $t_{\text {hitung }}$ sebesar 1,088 dan nilai sig. sebesar 0,286 , dimana $t_{\text {hitung }}<t_{\text {tabel }}(1,088<2,052)$ dan sig. $>0,05(0,286>$ 0,05). Hasil ini menunjukkan bahwa sistem perpajakan tidak berpengaruh dan tidak signifikan terhadap tindakan penggelapan pajak, sehingga $\mathbf{H}_{\mathbf{3}}$ ditolak. Variabel sanksi pajak diperoleh nilai $t_{\text {hitung }}$ sebesar 1,271 dan nilai sig. sebesar 0,214 , dimana $t_{\text {hitung }}<t_{\text {tabel }}(1,271<2,052)$ dan sig. $>0,05(0,214>0,05)$. Hasil ini menunjukkan bahwa sanksi pajak tidak berpengaruh dan tidak signifikan terhadap tindakan penggelapan pajak, sehingga $\mathbf{H}_{\mathbf{4}}$ ditolak.

Variabel keadilan pemungutan pajak dimoderasi religiusitas diperoleh nilai $\mathrm{t}_{\text {hitung }}$ sebesar $-0,072$ dan nilai sig. sebesar 0,943, dimana $-\mathrm{t}_{\text {hitung }}>-\mathrm{t}_{\text {tabel }}(-0,072>-$ 2,052) dan sig. > 0,05 $(0,943>0,05)$. Hasil ini menunjukkan bahwa religiusitas tidak dapat memperlemah pengaruh keadilan pemungutan pajak terhadap tindakan penggelapan pajak, sehingga $\mathbf{H}_{5}$ ditolak. Variabel norma subjektif dimodereasi religiusitas diperoleh nilai $t_{\text {hitung }}$ sebesar $-0,007$ dan nilai sig. sebesar 0,994 , dimana $-t_{\text {hitung }}>-t_{\text {tabel }}(-0,007>-2,052)$ dan sig. $>0,05(0,994>0,05)$. Hasil ini menunjukkan bahwa religiusitas tidak dapat memperlemah pengaruh norma subjektif terhadap tindakan penggelapan pajak, sehingga $\mathbf{H}_{\mathbf{6}}$ ditolak.

Variabel sistem perpajakan dimodereasi religiusitas diperoleh nilai $t_{\text {hitung }}$ sebesar $-0,600$ dan nilai sig. sebesar 0,553, dimana $-\mathrm{t}_{\text {hitung }}>-\mathrm{t}_{\text {tabel }}(-0,600>-2,052)$ dan sig. $>0,05(0,553>0,05)$. Hasil ini menunjukkan bahwa religiusitas tidak dapat memperlemah pengaruh sistem perpajakan terhadap tindakan penggelapan pajak, sehingga $\mathbf{H}_{7}$ ditolak. Variabel sanksi pajak dimodereasi religiusitas diperoleh nilai $t_{\text {hitung }}$ sebesar $-0,467$ dan nilai sig. sebesar 0,644 , dimana $-t_{\text {hitung }}>$ $\mathrm{t}_{\text {tabel }}(-0,467>-2,052)$ dan sig. $>0,05(0,644>0,05)$. Hasil ini menunjukkan bahwa religiusitas tidak dapat memperlemah pengaruh sanksi pajak terhadap tindakan penggelapan pajak, sehingga $\mathbf{H}_{\mathbf{8}}$ ditolak.

\section{Uji F}

Tabel 6. Hasil Uji F

\begin{tabular}{lccccc}
\hline \multicolumn{1}{c}{ Model } & Sum of Squares & $\boldsymbol{d} \boldsymbol{f}$ & Mean Square & $\boldsymbol{F}$ & Sig. \\
\hline Regression & 759,787 & 7 & 108,541 & 3,924 & 0,005 \\
Residual & 691,546 & 25 & 27,662 & & \\
Total & 1451,333 & 32 & & & \\
\hline
\end{tabular}

Sumber: data primer (diolah)

Berdasarkan Tabel 6, diperoleh nilai $\mathrm{F}_{\text {hitung }}$ sebesar 3,924 dan tingkat probabilitas sebesar 0,005 dan $F_{\text {tabel }}$ sebesar 2,570. Nilai $F_{\text {hitung }}>F_{\text {tabel }}(3,924>$ $2,570)$ dan nilai probabilitas $<0,05(0,005<0,05)$, artinya bahwa variabel bebas yaitu keadilan pemungutan pajak, norma subjektif, sistem perpajakan, sanksi pajak dan variabel moderasi yaitu religiusitas secara simultan berpengaruh signifikan terhadap variabel terikat yaitu tindakan penggelapan pajak. 


\section{Uji Koefisien Determinasi}

Berdasarkan Tabel 7, hasil model summary diperoleh nilai adjusted $R$ Square yaitu sebesar 0,390, hal ini berarti hanya 39\% tindakan penggelapan pajak dapat dijelaskan oleh keadilan pemungutan pajak, norma subjektif, sanksi pajak dan religiusitas. Sedangkan sisanya sebesar $61 \%$ dijelaskan oleh faktor lain selain faktor yang terdapat dalam penelitian ini.

Tabel 7. Hasil Uji Koefisien Determinasi

\begin{tabular}{ccccc}
\hline Model & $\boldsymbol{R}$ & $\boldsymbol{R}$ Square & $\begin{array}{c}\text { Adjusted } \boldsymbol{R} \\
\text { Square }\end{array}$ & $\begin{array}{c}\text { Std. Error of } \\
\text { the Estimate }\end{array}$ \\
\hline 1 & $0,724^{\mathrm{a}}$ & 0,524 & 0,390 & 5,259 \\
\hline
\end{tabular}

Sumber: data primer (diolah)

\section{Pengaruh Keadilan Pemungutan Pajak Terhadap Penggelapan Pajak}

Berdasarkan hasil hipotesis $\mathrm{H}_{1}$ yaitu ditolak, berarti keadilan pemungutan pajak berpengaruh tidak berpengaruh dan tidak signifikan terhadap tindakan penggelapan pajak. Keadilan pajak merupakan pembebanan pajak sesuai dengan kemampuan wajib pajak. Hal ini dapat disebabkan karena wajib pajak menganggap penggelapan pajak sebagai tindakan yang tidak benar meskipun manfaat pajak oleh wajib pajak belum sesuai, mereka tetap membayar pajak sebagai kewajiban kepada negara. Sehingga baik buruknya keadilan wajib pajak akan tetap menaati pemerintah. Usia responden yang sebagian besar sudah matang membuat mereka lebih patuh pada aturan dan undang-undang yang berlaku. Hasil penelitian ini mendukung penelitan yang dilakukan oleh Indriyani, Nurlaela, and Wahyuningsih (2016); Mujiyati, Rohmawati, and Ririn (2018); Karlina, Kurniawan, and Umiyati (2021) yang menyatakan bahwa keadilan pemungutan pajak tidak berpengaruh terhadap penggelapan pajak. Hasil penelitian ini bertolak belakang dengan penelitian yang dilakukan oleh Fatimah and Wardani (2017); Sondakh, Sabijono, and Pusung (2019) yang mengemukakan bahwa keadilan pemungutan pajak berpengaruh negatif secara signifikan terhadap penggelapan pajak

\section{Pengaruh Norma Subjektif Terhadap Penggelapan Pajak}

Berdasarkan hasil hipotesis $\mathrm{H}_{2}$ yaitu diterima, berarti norma subjektif berpengaruh negatif dan signifikan terhadap tindakan penggelapan pajak. Hal ini dapat mengindikasikan bahwa semakin tinggi tingkat norma subjektif, maka semakin rendah penggelapan pajak. Pengaruh tersebut dapat berasal dari saran atau ajakan orang terdekat untuk mematuhi peraturan perpajakan. Berdasarkan data responden, sebagian besar pengusaha memiliki pendidikan sarjana (strata 1), hal tersebut mengindikasikan kematangan cara mereka berpikir. Hasil penelitian ini mendukung penelitian yang dilakukan oleh Rahardianti (2020); Datulalong and Susanto (2021) menemukan bahwa norma subjektif berpengaruh negatif dan signifikan terhadap etis penggelapan pajak.

\section{Pengaruh Sistem Perpajakan Terhadap Penggelapan Pajak}

Berdasarkan hasil hipotesis $\mathrm{H}_{3}$ yaitu ditolak, berarti sistem perpajakan tidak berpengaruh dan tidak signifikan terhadap tindakan penggelapan pajak. Tidak berpengaruhnya sistem perpajakan terhadap penggelapan pajak dapat 
disebabkan karena pengawasan yang dilakukan oleh petugas pajak cukup baik, sehingga wajib pajak enggan melakukan tindakan penggelapan pajak. Pelaksanaan self assesment system dimana wajib pajak menghitung sendiri pajak yang terutang, tetap melalui proses pengecekan dan pengawasan yang dilakukan oleh petugas. Hasil penelitian ini mendukung penelitan yang dilakukan oleh Karlina, Kurniawan, and Umiyati (2021) yang menyatakan bahwa sistem perpajakan tidak berpengaruh terhadap penggelapan pajak. Hasil penelitian ini bertolak belakang dengan penelitian yang dilakukan oleh Paramita and Budiasih (2016); Rifani, Mursalim, and Ahmad (2019) yang menyatakan bahwa sistem perpajakan berpengaruh negatif dan signifikan terhadap penggelapan pajak.

\section{Pengaruh Sanksi Pajak Terhadap Penggelapan Pajak}

Berdasarkan hasil hipotesis $\mathrm{H}_{4}$ yaitu ditolak, artinya sanksi pajak tidak berpengaruh dan tidak signifikan terhadap tindakan penggelapan pajak. Hal ini mengisyaratkan bahwa wajib pajak sudah memahami sanksi pajak yang diberikan ketika melanggar, sehingga wajib pajak tidak akan melakukan tindakan penggelapan pajak. Sebagian besar dari pengusaha telah lebih dari 5 tahun menjadi wajib pajak sehingga mereka sangat memahami konsekuensi dari pelanggaran pajak. Hasil penelitian ini mendukung penelitan yang dilakukan oleh Helweldery, Allolayuk, and Matani (2019) menemukan bahwa sanksi pajak tidak berpengaruh terhadap penggelapan pajak. Hasil penelitian ini bertolak belakang dengan penelitian yang dilakukan oleh Maghfiroh and Fajarwati (2016); Wijaya and Jannah (2017) yang menyatakan sanksi pajak berpengaruh negatif dan signifikan terhadap persepsi wajib pajak mengenai etika penggelapan pajak.

\section{Pengaruh Keadilan Pemungutan Pajak Terhadap Penggelapan Pajak Dengan Religiusitas Sebagai Variabel Moderasi}

Berdasarkan hasil hipotesis $\mathrm{H}_{5}$ yaitu ditolak, berarti religiusitas tidak dapat memperlemah pengaruh keadilan pemungutan pajak terhadap tindakan penggelapan pajak. Hal ini disebabkan karena keadilan pemungutan pajak merupakan syarat yang harus dilakukan pada saat pemungutan pajak dan sebagai tujuan hukum untuk mencapai keadilan. Adanya religiusitas tidak dapat mempengaruhi baik buruknya keadilan pemungutan pajak karena pembayaran pajak adalah suatu kewajiban wajib pajak dalam membayar pajak. Sehingga dapat dijelaskan bahwa religiusitas tidak dapat memoderasi hubungan antara keadilan pemungutan pajak dengan penggelapan pajak. Hasil penelitian ini didukung oleh penelitian Liefa and Dewi (2020) yang menyatakan bahwa bahwa religiusitas tidak dapat memoderasi variabel bebas dengan variabel terikat.

\section{Pengaruh Norma Subjektif Terhadap Penggelapan Pajak Dengan Religiusitas Sebagai Variabel Moderasi}

Berdasarkan hasil hipotesis $\mathrm{H}_{6}$ yaitu ditolak, berarti religiusitas tidak dapat memperlemah pengaruh norma subjektif terhadap tindakan penggelapan pajak. Hal ini disebabkan karena wajib pajak lebih mendengarkan orang lain dan menganggap orang lain lebih penting dari pendapat sendiri. Berdasarkan perspektif teori fraud triangle memberikan motivasi individu melakukan tindakan penggelapan pajak, dimana tekanan dari luar akan membuat wajib pajak semakin terdesak melakukan kecurangan dengan ancaman yang diberikan. Religiusitas 
seseorang dapat berubah dan cenderung mengutamakan pendapat orang lain yang menjadi motivasi. Menurut Bawono and Oktaviani (2016) bahwa seseorang harus menjalankan ajaran agama secara menyeluruh. Sehingga dengan alasan tersebut tinggi rendahnya religiusitas tidak dapat memoderasi antara norma subjektif terhadap penggelapan pajak.

\section{Pengaruh Sistem Perpajakan Terhadap Penggelapan Pajak Dengan Religiusitas Sebagai Variabel Moderasi}

Berdasarkan hasil hipotesis $\mathrm{H}_{7}$ yaitu ditolak, berarti religiusitas tidak dapat memperlemah pengaruh sistem perpajakan terhadap tindakan penggelapan pajak. Hal tersebut mengindikasikan bahwa persepsi seseorang yang dapat memilah, sehingga tinggi rendahnya tingkat religiusitas tidak dapat memperlemah pengaruh sistem perpajakan terhadap penggelapan pajak. Kemudian hal tersebut juga disebabkan karena sistem perpajakan mengharus wajib pajak menghitung sendiri jumlah pajak yang terutang. Apabila dihubungkan dengan teori fraud, dimana kecurangan yang dapat dilakukan pada saat mengalami tekanan dan adanya kesempatan dengan menghitung sendiri jumlah pajak yang terutang. Wajib pajak dapat mengesampingkan kereligiusannya. Sehingga tinggi rendahnya religiusitas yang dimiliki wajib pajak tidak dapat memoderasi hubungan antara sistem perpajakan terhadap penggelapan pajak. Hasil penelitian yang mendukung adalah Atmoko (2021) yang tidak dapat membuktikan moderasi religiusitas terhadap hubungan antara self assessment system terhadap tindakan penggelapan pajak.

\section{Pengaruh Sanksi Pajak Terhadap Penggelapan Pajak Dengan Religiusitas Sebagai Variabel Moderasi}

Berdasarkan hasil hipotesis $\mathrm{H}_{8}$ yaitu ditolak, berarti religiusitas tidak dapat memperlemah pengaruh sanksi pajak terhadap tindakan penggelapan pajak. Hal tersebut mengindikasikan bahwa wajib pajak yang telah memahami sanksi pajak, namun kebanyakan mereka mengabaikannya karena menganggap sanksi yang ditetapkan tidak sesuai dengan apa yang di perbuat dan sudah banyak yang terungkap kasus penggelapan pajak. Berdasarkan teori fraud triangle menjelaskan adanya tekanan dan anggapan bahwa kecurangan pajak sebagai tindakan yang rasional karena sudah banyak yang melakukan penggelapan pajak. Menurut Indrapraja, Agusti, and Mela (2021) hukuman setelah melakukan tindakan kecurangan dengan melanggar agama tidak dapat dirasakan dalam jangka waktu dekat. Sehingga tinggi rendahnya religiusitas tidak dapat memoderasi hubungan antara sanksi pajak terhadap penggelapan pajak.

Berdasarkan hasil temuan yang ada, maka dapat dikatakan bahwa variable yang digunakan belum tepat dalam menggambarkan tindakan penggelapan pajak yang terjadi di kota Salatiga. Fenomena ini bermula dari tingkat penerimaan pajak yang belum sesuai target di kota Salatiga yang mendindikasikan adanya bentuk pelanggaran terhadap aturan pajak. Namun perlu diperhatikan bahwa responden penelitian ini adalah pengusaha yang sudah terdaftar sebagai wajib pajak. Jumlah ini masih sangat sedikit dibandingkan jumlah UMKM, sehingga penelitian ini membutuhkan kelanjutan dimasa yang akan datang khususnya terkait dengan penelitian terhadap pengusaha yang belum mendaftarkan diri sebagai wajib pajak. 


\section{KESIMPULAN}

Bahwa ternyata keadilan pemungutan pajak, sistem perpajakan, dan sanksi pajak tidak berpengaruh terhadap tindakan penggelapan pajak. Sedangkan norma subjektif berpengaruh negatif dan signifikan terhadap tindakan penggelapan pajak. Kemudian religiusitas tidak dapat memoderasi pengaruh antara keadilan pemungutan pajak, norma subjektif, sistem perpajakan dan sanksi pajak terhadap tindakan penggelapan pajak. Selanjutnya keadilan pemungutan pajak, norma subjektif, sistem perpajakan, sanksi pajak dan religiusitas secara simultan berpengaruh signifikan terhadap tindakan penggelapan pajak, dengan pengaruh sebesar $39 \%$.

Hasil temuan ini dapat dijadikan sebagai acuan bagi kantor pelayanan pajak pratama kota Salatiga untuk lebih giat dalam mengedukasi pengusaha UMKM untuk sadar akan pajak. Hal ini sangat penting karena pajak merupakan salah satu sumber pendapatan daerah yang dapat digunakan untuk mendukung pembangunan daerah secara berkelanjutan. Peran semua pihak terutama pengusaha akan sangat membantu pemerintah daerah dalam mewujudkan infrastruktur yang memadai bagi masyarakat secara umum.

Beberapa keterbatasan dalam penelitian ini adalah penggunaan variabel keadilan pemungutan pajak, norma subjektif, sistem perpajakan, sanksi pajak dan religiusitas sebagai moderasi yang masih kurang tepat, sehingga terdapat faktor lain yang menyebabkan wajib pajak melakukan tindakan penggelapan pajak. Kemudian selain itu jumlah responden kurang memadai sehingga tidak dapat menggambarkan kondisi secara umum, sehingga penelitian lanjutan diperlukan dengan menambahkan variable lain yang mungkin lebih tepat untuk penelitian ini. Pemilihan responden dan jumlahnya juga perlu dilakukan lebih luas lagi agar mampu menggambarkan kondisi yang sebenarnya.

\section{DAFTAR PUSTAKA}

Agus, Yolisia Framita, Indah Umiyati, and Asep Kurniawan. 2019. "Determinants and Mitigation Factors of Tax Evasion: Indonesia Evidence." ACCRUALS (Accounting Research Journal of Sutaatmadja) 3(2): 226-246. https://doi.org/10.35310/accruals.v3i2.117.

Ajzen, Icek. 1991. "The Theory of Planned Behavior." Organizational Behavior and Human Decision Process 50 (2): 179-211. https://doi.org/10.1016/0749-5978(91)90020-T.

Ardi, Devi Marta, Trimurti Trimurti, and Suhendro Suhendro. 2016. "Pengaruh Persepsi Wajib Pajak Orang Pribadi Terhadap Tindakan Penggelapan Pajak di Kota Surakarta." Prosiding Industrial Engineering National Conference (IENACO): IENACO (Industrial Engineering National Conference) 2016. http://hdl.handle.net/11617/7169.

Atmoko, Alfriadi Dwi. 2021. "Does Intrinsic Religiosity Moderate Between The Self- Assessment System And Tax Evasion? A Research-Based On Gender." ASSETS: Jurnal Akuntansi dan Pendidikan 10 (2): 123-131. http://doi.org/10.25273/jap.v10i2.5105.

Bawono, Anton, and Milatunnikmah Finisia Rahajeng Oktaviani. 2016. "Analisis 
Pemahaman, Produk, Dan Tingkat Religiusitas Terhadap Keputusan Mahasiswa IAIN Menjadi Nasabah Bank Syariah Cabang Salatiga." MUQTASID: Jurnal Ekonomi dan Perbankan Syariah 7 (1): 29-53. https://doi.org/10.18326/muqtasid.v7i1.29-53.

Cressey, Donald R. 1950. "The Criminal Violation of Financial Trust." American Sociological Review 15 (6): 738-743. https://doi.org/10.2307/2086606.

Datulalong, Yudithia Maria, and Yulius Kurnia Susanto. 2021. "Faktor-Faktor Yang Mempengaruhi Persepsi Wajib Pajak Terhadap Tax Evasion Di Jakarta." E-Jurnal Akuntansi TSM 1 (1): 1-12. https://jurnaltsm.id/index.php/EJATSM/article/view/966.

Dharma, Lasmia, Restu Agusti, and Pipin Kurnia. 2016. "Pengaruh Gender, Pemahaman Perpajakan Dan Religiusitas Terhadap Persepsi Penggelapan Pajak." Jurnal Online Mahasiswa Fakultas Ekonomi 3 (1): 1565-1578. https://jom.unri.ac.id/index.php/JOMFEKON/article/view/11764.

Fatimah, Siti, and Dewi Kusuma Wardani. 2017. "Faktor-Faktor Yang Mempengaruhi Penggelapan Pajak Di Kantor Pelayanan Pajak Pratama Temanggung." Akuntansi Dewantara 1 (1): 1-14. https://doi.org/10.29230/ad.v1i1.20.

Felicia, Icha, and Teguh Erawati. 2017. "Pengaruh Sistem Perpajakan, Sanksi Perpajakan Dan Tarif Pajak Terhadap Persepsi Wajib Pajak Mengenai Etika Penggelapan Pajak.” Kajian Bisnis Sekolah Tinggi Ilmu Ekonomi Widya Wiwaha $25 \quad$ (2): 226-234. http://jurnal.stieww.ac.id/index.php/jkb/article/view/139.

Ghozali, Imam. 2018. Aplikasi Analisis Multivariate Dengan Program Ibm Spss 25, 9th ed. Semarang: Universitas Diponegoro.

Hanindita, Dysna Pratiwi, and Endang Dwi Retnani. 2019. "Faktor - Faktor Yang Mempengaruhi Wajib Pajak Dalam Membayar Pajak UMKM Kota Surabaya." Jurnal Ilmu dan Riset Akuntansi (JIRA) 8 (10): 1-19. http://jurnalmahasiswa.stiesia.ac.id/index.php/jira/article/view/2683.

Haq, Rivan Aulia, and Ayu Fury Puspita. 2019. "Determinan Persepsi Wajib Pajak Badan Mengenai Etika Penggelapan Pajak (Studi Pada Wajib Pajak Badan Yang Terdaftar Di Kantor Pelayanan Pajak Pratama Purwakarta)." Jurnal Ekonomi Dan Bisnis "E-QIEN" 6 (2): 89-100. https://doi.org/10.34308/eqien.v6i2.82.

Helweldery, Bryando, Theo Allolayuk, and Cornelia D. Matani. 2019. "FaktorFaktor Yang Mempengaruhi Persepsi Wajib Pajak Orang Pribadi Terhadap Etika Penggelapan Pajak (Studi Empiris Pada Wajib Pajak Terdaftar Di KPP Pratama Jayapura).” Jurnal Akuntansi Dan Keuangan Daerah 14 (2): 25-37. https://doi.org/10.52062/jakd.v14i2.1453.

Indrapraja, M. Haykal Daditullah, Restu Agusti, and Nanda Fito Mela. 2021. "Pengaruh Gaya Kepemimpinan, Budaya Organisasi, Kompetensi Dan Religiusitas Terhadap Kecurangan (Fraud) Aparatur Sipil Negara." CURRENT: Jurnal Kajian Akuntansi Dan Bisnis Terkini 2 (2): 166-183. https://doi.org/10.31258/jc.2.2.166-183.

Indriyani, Mila, Siti Nurlaela, and Endang Masitoh Wahyuningsih. 2016. "Pengaruh Keadilan, Sistem Perpajakan, Diskriminasi, dan Kemungkinan Terdeteksinya Kecurangan Terhadap Persepsi Wajib Pajak Orang Pribadi Mengenai Perilaku Tax Evasion." Prosiding Industrial Engineering 
National Conference (IENACO): IENACO (Industrial Engineering National Conference) 2016. http://hdl.handle.net/11617/7163.

Karlina, Yuliani, Asep Kurniawan, and Indah Umiyati. 2021. "Faktor-Faktor Yang Mempengaruhi Niat Melakukan Penggelapan Pajak.” JASS (Journal of Accounting for Sustainable Society) 2 (2): 28-54. https://doi.org/10.35310/jass.v2i02.670.

Koster, Ferry, Heike Goudriaan, and Coen van der Schans. 2009. "Shame and Punishment: An International Comparative Study on the Effects of Religious Affiliation and Religiosity on Attitudes to Offending." European $\begin{array}{lllll}\text { Journal of } & \text { Criminology } & 6 & \text { (6): }\end{array}$ https://doi.org/10.1177/1477370809341129.

Kusnadi, Kusnadi, and Desi Rinika. 2019. "Pengaruh Keadilan Pajak, Sistem Pemungutan Pajak, Sanksi Keterlambatan Perpajakan, Dan Diskriminasi Pajak Terhadap Penggelapan Pajak." Jurnal Riset Akuntansi dan Manajemen Malahayati $8 \quad$ (2): http://ejurnalmalahayati.ac.id/index.php/risetekonomi/article/view/2614

Liefa, Theresia, and Sofia Prima Dewi. 2020. "Pengaruh Money Ethics Dan Keadilan Terhadap Tax Evasion Dengan Religiosity Sebagai Pemoderasi." Jurnal Paradigma Akuntansi 2 (3) 1086-1095. http://journal.untar.ac.id/index.php/jpa/article/view/9534.

Maghfiroh, Dhinda, and Diana Fajarwati. 2016. "Persepsi Wajib Pajak Mengenai Pengaruh Keadilan, Sistem Perpajakan Dan Sanksi Perpajakan Terhadap Penggelapan Pajak." JRAK: Jurnal Riset Akuntansi \& Komputerisasi Akuntansi 7 (1): 39-55. https://jurnal.unismabekasi.ac.id/index.php/jrak/article/view/643.

Makrifah, Lailizakiatul, and Yudha Trishananto. 2021. "Pengaruh Bukti Fisik, Layanan, Dan Religiusitas Terhadap Loyalitas Dengan Kepuasan Sebagai Intervening." Jurnal Ekobis: Ekonomi, Bisnis \& Manajemen 11 (2): 330341. http://ejournal.stiemj.ac.id/index.php/ekobis/article/view/306.

Mardiasmo, Mardiasmo. 2016. Perpajakan. Yogyakarta: CV. Andi Offset.

Marlina, Marlina. 2018. "Analisis Faktor-Faktor Yang Mempengaruhi Persepsi Wajib Pajak Orang Pribadi Mengenai Penggelapan Pajak Pada KPP Pratama Lubuk Pakam." Jurnal Pundi 2 (2): 151-168. https://doi.org/10.31575/jp.v2i2.82.

Mujiyati, Mujiyati, Fitria Riski Rohmawati, and Wahyu Hening Ririn. 2018. "Determinan Persepsi Mengenai Etika Atas Penggelapan Pajak (Tax Evasion)." Riset Akuntansi Dan Keuangan Indonesia (REAKSI) 3 (1): 112. https://doi.org/10.23917/reaksi.v3i1.5551.

Nugroho, Andrianto Dwi. 2017. Hukum Pidana Pajak Indonesia. Bandung: PT. Citra Aditya Bakti.

Palil, Mohd Rizal, Mohd Akir Rusyidi, and Wan Fadillah Bin Wan Ahmad. 2013. "The Perception of Tax Payers on Tax Knowledge and Tax Education with Level of Tax Compliance: A Study the Influences of Religiosity." ASEAN Journal of Economics, Management and Accounting 1 (1): 118-129. http://fem.ipb.ac.id/miicema/e-journal/v1n1/8.pdf.

Palupi, Atika Oktaviani. 2013. Pengaruh Religiusitas Terhadap Kenakalan Remaja Pada Siswa Kelas VIII SMP Negeri 02 Slawi Kabupaten Tegal. Skripsi Universitas Negeri Semarang. http://lib.unnes.ac.id/18333/. 
Paramita, A. A. Mirah Pradnya, and I Gusti Ayu Nyoman Budiasih. 2016. "Pengaruh Sistem Perpajakan, Keadilan, Dan Teknologi Perpajakan Pada Persepsi Wajib Pajak Mengenai Penggelapan Pajak." E-Jurnal Akuntansi 17 1030-1056. https://ojs.unud.ac.id/index.php/Akuntansi/article/view/19884.

Priantara, Diaz. 2013. Fraud Auditing \& Investigation. Jakarta: Mitra Wacana Media.

Purwati, Isni. 2016. Pengaruh Motivasi, Lingkungan Kerja Dengan Religiusitas Sebagai Variabel Moderating Terhadap Produktivitas Kerja Karyawan (Studi Kasus PT. Daya Manunggal Di Salatiga). Skripsi IAIN Salatiga. http://e-repository.perpus.iainsalatiga.ac.id/953/.

Rahardianti, Elfitri Dwi. 2020. Determinan Persepsi Etis Penggelapan Pajak. Skripsi Universitas Islam Indonesia. https://dspace.uii.ac.id/handle/123456789/23894.

Rifani, Riza Amalia, Mursalim Mursalim, and Hamzah Ahmad. 2019. "Pengaruh Keadilan, Sistem Perpajakan Dan Kualitas Pelayanan Terhadap Penggelapan Pajak." PARADOKS : Jurnal Ilmu Ekonomi 2 (3): 131-144. http://jurnal.fe.umi.ac.id/index.php/PARADOKS/article/view/266.

S., Alam. 2014. Pengantar Ekonomi Dan Bisnis. Jakarta: PT. Gelora Aksara Pratama.

Sondakh, Thessa F.Y, Harijanto Sabijono, and Rudy J. Pusung. 2019. "Pengaruh Keadilan Pemungutan Pajak, Pemahaman Perpajakan Dan Pelayanan Aparat Pajak Terhadap Tindakan Penggelapan Pajak (Studi Empiris Pada Wajib Pajak Orang Pribadi Di KPP Pratama Manado)." Jurnal EMBA: Jurnal Riset Ekonomi, Manajemen, Bisnis Dan Akuntansi 7 (3): 31093118. https://ejournal.unsrat.ac.id/index.php/emba/article/view/24067.

Stack, Steven, and Augustine Kposowa. 2006. "The Effect of Religiousity on Tax Fraud Acceptability: A Cross National Analysis." Journal For The Scientific Study of Religion 45 (3): 325-351. https://doi.org/10.1111/j.1468-5906.2006.00310.x.

Sundari, Sundari. 2019. "Pengaruh Sanksi Perpajakan dan Self Assessment System terhadap Persepsi Wajib Pajak Mengenai Penggelapan Pajak (Tax Evasion)." Jurnal Kajian Akuntansi 3 (1): 55-67. http://jurnal.ugj.ac.id/index.php/jka/article/view/2114.

Surahman, Wanda, and Ulinnuha Yudiansa Putra. 2018. "Faktor-Faktor Persepsi Wajib Pajak Terhadap Etika Penggelapan Pajak." Jurnal REKSA: Rekayasa Keuangan, Syariah Dan Audit 5 (1): 1-10. https://doi.org/10.12928/j.reksa.v5i1.140.

Suryaputri, Rossje Vitarimetawatty, and Ancilla Regina Averti. 2019. "Pengaruh Keadilan Perpajakan, Sistem Perpajakan, Diskriminasi Perpajakan, Kepatuhan Wajib Pajak Terhadap Penggelapan Pajak." Jurnal Akuntansi Trisakti 5 (1): 109-122. http://dx.doi.org/10.25105/jat.v5i1.4851.

Wanarta, Feby Eileen, and Yenni Mangoting. 2014. "Pengaruh Sikap Ketidakpatuhan Pajak, Norma Subjektif, dan Kontrol Perilaku yang Dipersepsikan terhadap Niat Wajib Pajak Orang Pribadi untuk Melakukan Penggelapan Pajak." Tax \& Accounting Review 4 (1): 138-150. http://publication.petra.ac.id/index.php/akuntansi-pajak/article/view/3112.

Wijaya, Angka, and Miftahul Jannah. 2017. "Beberapa Faktor Yang 
Mempengaruhi Persepsi Wajib Pajak Orang Pribadi Atas Perilaku Penggelapan Pajak." Jemasi: Jurnal Ekonomi Manajemen Dan Akuntansi 13 (1): 87-111. https://doi.org/10.35449/jemasi.v13i1.7.

\section{LAMPIRAN}

Target dan Realisasi Penerimaan PPH

\begin{tabular}{cccc}
\hline Tahun & Target & Realisasi & $\begin{array}{c}\text { Persentase } \\
\text { Penerimaan Pajak }\end{array}$ \\
\hline 2015 & 548.805 .999 .657 & 508.091 .400 .108 & $92,59 \%$ \\
2016 & 840.688 .073 .000 & 566.210 .075 .775 & $67,36 \%$ \\
2017 & 867.638 .899 .000 & 518.452 .461 .071 & $59,76 \%$ \\
2018 & 710.573 .647 .000 & 577.348 .853 .900 & $81,26 \%$ \\
2019 & 750.056 .305 .000 & 696.505 .403 .911 & $92,87 \%$ \\
2020 & 571.005 .044 .000 & 548.853 .759 .381 & $96,13 \%$ \\
\hline
\end{tabular}

Sumber: Kantor Pelayanan Pajak Pratama Salatiga

\section{Tingkat Kepatuhan Wajib Pajak Orang Pribadi}

\begin{tabular}{cccc}
\hline Tahun & $\begin{array}{c}\text { Jumlah Wajib } \\
\text { Pajak Terdaftar }\end{array}$ & $\begin{array}{c}\text { Jumlah Wajib } \\
\text { Pajak Lapor }\end{array}$ & Persentase \\
\hline 2015 & 29,688 & 14,286 & $48,12 \%$ \\
2016 & 31,813 & 15,137 & $47,58 \%$ \\
2017 & 33,877 & 14,945 & $44,12 \%$ \\
2018 & 36,456 & 14,866 & $40,78 \%$ \\
2019 & 39,106 & 16,540 & $42,30 \%$ \\
2020 & 51,853 & 15,164 & $29,24 \%$ \\
\hline
\end{tabular}

Sumber: Kantor Pelayanan Pajak Pratama Salatiga 